\title{
PENGEMBANGAN MODEL KESELAMATAN UNTUK PENYEBERANGAN JALAN KOTA BANDUNG (STUDI KASUS SIMPANG BERSINYAL)
}

\author{
Istiqomah Nurhidayati ${ }^{1}$, Aine Kusumawat ${ }^{2}$, Sri Hendarto ${ }^{3}$ \\ Program Studi Magister Sistem dan Teknik Jalan Raya 1,2,3 \\ Fakultas Teknik Sipil dan Lingkungan, Institut Teknologi Bandung \\ Jl. Ganesha no. 10, Bandung 40132 \\ icheiche31@gmail.com $^{1}$, aine kusumawati@yahoo.com ${ }^{2}$, hendartosri@gmail.com $^{3}$
}

\section{Abstrak}

Kecelakaan lalu lintas menjadi penyebab utama kematian peringkat ke-10 di Kota Bandung. Pejalan kaki adalah pengguna jalan yang rentan terhadap kecelakaan. Kecelakaan pejalan kaki sering terjadi di simpang karena pengguna jalan yang beragam dan bergerak menggunakan ruang jalan yang sama sehingga menimbulkan interaksi antara pengguna jalan yang kompleks. Keselamatan pejalan kaki di simpang masih sangat rendah sehingga penting dilakukan sebuah studi untuk mengurangi jumlah kecelakaan pejalan kaki. Sebuah model yang telah dikembangkan oleh FHWA (Federal Highway Adminstration) untuk keselamatan pejalan kaki di simpang adalah model PedISI (Pedestrian Intersection Safety Index). Model ini dapat digunakan untuk menentukan simpang mana yang perlu ditangani sebelum terjadi kecelakaaan berdasarkan nilai PedISI. Nilai PedISI menunjukkan tingkat keselamatan pejalan kaki di simpang. Tesis ini mengembangkan model Pedestrian Intersection Safety Index (PedISI) untuk simpang bersinyal Kota Bandung dengan variabel-variabel yang dimodifikasi. Data yang digunakan untuk pengembangan model adalah data kecelakaan pejalan kaki, data karakteristik simpang, data perilaku (konflik) dan data nilai keselamatan. Lokasi penelitian terdiri dari 16 simpang bersinyal dengan tipe 8/2 D, 6/2 D, 4/2 D, 4/2 UD dan 2/2 UD. Model PedISI yang terbentuk untuk Simpang Bersinyal Kota Bandung adalah PedISI $=3,184+$ 0,032 THRULNS - 0,005 MEDIAN + 0,001 SPEED85th dengan $R 2=0,525$. Nilai PedISI untuk Simpang Bersinyal Kota Bandung berdasarkan model tersebut adalah 3,24 - 3,45. Besar rata-rata nilai PedISI sebesar 3,35 dengan standar deviasi 0,06.
\end{abstract}

Model mampu menggambarkan kondisi keselamatan simpang namun memiliki variasi nilai PedISI yang kecil. Hal ini disebabkan oleh hasil survei yang mengindikasikan adanya keseragaman persepsi responden terhadap nilai keselamatan. Dengan demikian, diperlukan perbaikan teknik pengumpulan data nilai keselamatan agar diperoleh model yang lebih baik.

Kata kunci :

penyeberangan jalan, pejalan kaki, keselamatan, kecelakaan, Pedestrian Intersection Safety Index (PedISI).

\begin{abstract}
Traffic crashes are the 10th main cause of death in Bandung. Pedestrians are road users who are more vulnerable to crashes. Pedestrian crashes often occur at intersections as diverseroad users move in the same road space, thus making interaction between road users more complex. Currently, pedestrian safety at intersection is still very low, so it is important to do a study to reduce the number of pedestrian crashes. A model that has been developed by FHWA (Federal Highway Adminstration) for pedestrian safety at intersection is PedISI (Pedestrian Intersection Safety Index). This model can be used to determine which intersections need to be addressed before a crash occurs based on PedISI values. PedISI values show the level of pedestrian safety at intersection. This thesis develops Pedestrian Intersection Safety Index (PedISI) model for signalized intersection in Bandung. The data used consist of pedestrian crashes data, intersection characteristic data, behavioral(conflicts) data and
\end{abstract}


safety rating data. Data were collected from 16 signalized intersections of types $8 / 2 D, 6 / 2 D, 4 / 2 D$, 4/2 UD and 2/2 UD. PedISI model formed for signalized intersection in Bandung is PedISI $=3,184$ + 0,032THRULNS - 0,005MEDIAN + 0,001 SPEED85th with $R 2=0,525$. PedISI values for signalized intersections in Bandung based on the model is 3,24-3,45. The average value of PedISI is 3,35 with a standard deviation of 0,06. This model is able to describe the safety conditions of intersection though it has small variation in PedISI values. This is due to the results of surveys that indicated uniformity in respondents perceptions of safety rating values. Thus, it is necessary to improve the safety data collection techniques to obtain a better model.

Keywords :

crosswalks, pedestrian, safety, crash, Pedestrian Intersection Safety Index (PedISI).

\section{Pendahuluan}

Keselamatan jalan merupakan isu global yang hangat diperbincangkan dalam beberapa tahun terakhir. Sejalan dengan pesatnya pertumbuhan kendaraan bermotor yang dikombinasikan dengan meningkatnya jumlah penduduk dan jenis kendaraan yang beragam menyebabkan masalah keselamatan jalan semakin memburuk. Indikator utama yang sering digunakan dalam menilai keselamatan jalan adalah kecelakaan lalu lintas. Kecelakaan lalu lintas diprediksi akan menjadi penyebab utama kematian peringkat ke 7 pada tahun 2030 di dunia.

Kota Bandung sebagai ibukota Provinsi Jawa Barat dihuni oleh 2.490.479 jiwa yang akan meningkat setiap tahunnya. Peningkatan jumlah penduduk berakibat pada aktivitas yang semakin padat dan mobilitas yang tinggi sehingga tidak heran pertumbuhan kendaraan bermotor di Kota Bandung terus meningkat. Ledakan jumlah kendaraan bermotor menjadi pemicu permasalahan transportasi karena penambahan ruas jalan tidak sebanding dengan penambahan jumlah kendaraan bermotor sehingga menjadi salah satu faktor penyebab kecelakaan lalu lintas. Walaupun jumlah kecelakaan lalu lintas di Kota Bandung menurun secara bertahap dari tahun 2013 hingga 2016 namun intervensi untuk meningkatkan keselamatan masih dibutuhkan guna mengurangi jumlah korban yang mayoritas berusia muda dan produktif.
Pejalan kaki adalah pengguna jalan yang teramat rentan. Dalam kejadian tabrakan dengan kendaraan bermotor, pejalan kaki paling berisiko cidera dengan tingkat fatalitas yang tinggi. Hal ini menyoroti kebutuhan mendesak untuk menangani keselamatan terhadap pejalan kaki.

Simpang secara khusus merupakan lokasi yang berisiko tinggi menjadi tempat terjadinya kecelakaan karena volume lalu lintasnya tinggi dan pengguna jalannya beragam yang bergerak dengan menggunakan ruang jalan yang sama sehingga terjadi interaksi antara pengguna jalan yang kompleks. Peningkatan keselamatan di simpang dapat mengurangi jumlah kecelakaan lalu lintas secara signifikan sehingga keselamatan di simpang harus selalu diperhatikan terutama dalam aspek fasilitas penyeberangan.

Salah satu model proaktif yang telah dikembangkan untuk keselamatan pejalan kaki pada simpang adalah model PedISI (Pedestrian Intersection Safety Index). Model PedISI telah dikembangkan oleh FHWA (Federal Highway Administration) dengan menggunakan regresi linier berdasarkan data karakteristik simpang, data kecelakaan, data konflik antara pejalan kaki dengan kendaraan bermotor dan data nilai keselamatan bagi pejalan kaki di simpang. Dalam model ini, pengaruh kondisi data yang berbeda terhadap keselamatan pejalan kaki belum dipertimbangkan sehingga model ini perlu dikembangkan.

Dengan melakukan pengembangan model, dapat dibahas variabel yang teridentifikasi berpengaruh terhadap keselamatan untuk penyeberangan jalan Kota Bandung dan besarnya nilai indeks keselamatan suatu simpang. Diharapkan dengan terbentuknya model untuk penyeberangan jalan Kota Bandung, penanganan terhadap keselamatan dapat dilakukan pada simpang yang tepat sehingga mampu mencegah terjadinya kecelakaan pejalan kaki secara maksimal.

\section{KAJIAN LITERATUR}

Salah satu model yang dapat digunakan untuk peningkatan keselamatan melalui ukuran statistik adalah model Pedestrian Intersection Safety Index (PedISI). Model PedISI merupakan pengembangan dari indeks keselamatan bagi pejalan kaki secara makro (Carter et al., 2007). Model ini dikembangkan oleh FHWA dengan tujuan mempermudah para

Istiqomah Nurhidayati, Aine Kusumawat, Sri Hendarto 
insinyur, perencana dan praktisi lain untuk menggunakan karakteristik simpang guna secara proaktif memprioritaskan keselamatan pejalan kaki di kawasan penyeberangan jalan dan pendekat pada simpang.

Dengan menggunakan variabel-variabel yang menunjukkan kemungkinan resiko yang lebih tinggi bagi pejalan kaki, PedISI dapat digunakan untuk mengidentifikasi kawasan penyeberangan jalan dan pendekat simpang yang memiliki prioritas tertinggi untuk peningkatan keselamatan pejalan kaki dalam yuridiksi tertentu. Setelah lokasi dengan prioritas tinggi teridentifikasi, praktisi dapat melakukan evaluasi yang lebih mendalam pada setiap lokasi untuk menentukan tindakan penanganan yang paling tepat untuk permasalahan keselamatan yang ada.

Pengembangan model PedISI mengikuti langkahlangkah dasar sebagai berikut:

1. Pemilihan lokasi studi

2. Pengumpulan data karakteristik simpang

3. Pengumpulan data keselamatan terhadap simpang yang dikaji

4. Menghubungkan data karakteristik simpang dengan keselamatan simpang

5. Membentuk indeks keselamatan pejalan kaki di simpang

Perbedaan karakteristik pendekat simpang dapat mempengaruhi keselamatan pejalan kaki. Model PedISI lebih ditujukan untuk mengevaluasi keselamatan pejalan kaki pada setiap pendekat di persimpangan tertentu dibandingkan untuk mengevaluasi keselamatan pejalan kaki pada simpang secara keseluruhan.

Pokok dari pengembangan model PedISI terdiri dari 4 (empat) langkah untuk mengukur keselamatan yaitu kecelakaan, perilaku (konflik dan menghindari manuver) dan penilaian berdasarkan ahli atau pendapat pengguna yang digambarkan dalam konsep piramida dalam Gambar 1.

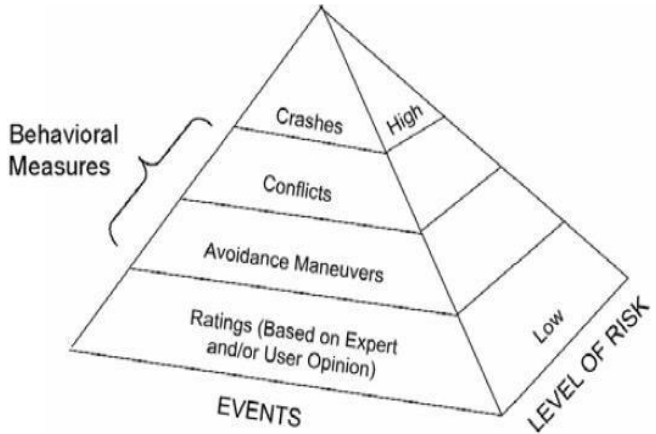

Gambar 1 Hirarki Pengukuran Keselamatan

(Carter et al., 2007)

Pemilihan lokasi dalam model PedISI oleh FHWA berdasarkan hasil pertemuan panel para ahli untuk mengumpulkan pendapat mengenai faktorfaktor penting dari simpang yang mendasari masalah keselamatan pejalan kaki. Karakteristik simpang pada lokasi yang ditinjau untuk model PedISI yang dikembangkan oleh FHWA adalah sebagai berikut:

1. Jenis pengontrol lalu lintas (sinyal atau rambu henti)

2. Jumlah lajur (dua lajur,empat lajur dan lain-lain)

3. Jenis median (tidak terbagi atau terbagi)

4. Ada atau tidaknya parkir di jalan

5. Berbagai volume pejalan kaki dan volume lalu lintas

Data yang dikumpulkan meliputi data karakteristik fisik, data kecelakaan, data perilaku dan data penilaian keselamatan secara subjektif. Pengumpulan data simpang dan rekaman video di lokasi dilakukan dengan bantuan pengumpulan data lokal dari setiap kota.

\section{Data karakteristik fisik}

Data karakteristik fisik meliputi data geometrik simpang, pengontrol lalu lintas dan fasilitas bagi pejalan kaki. Data ini digunakan sebagai variabel bebas dalam analisis regresi untuk memprediksi indeks keselamatan simpang.

\section{Data kecelakaan}

Data historis kecelakaan merupakan data yang paling umum digunakan untuk pengukuran keselamatan suatu lokasi. Dalam penelitian ini, data kecelakaan yang ada hanya sebagai yurisdiksi. Hal ini dikarenakan data kecelakaan pada banyak kasus, tidak 
memiliki informasi lokasi yang cukup untuk menentukan posisi kecelakaan di simpang.

\section{Data perilaku}

Data perilaku digunakan sebagai informasi tambahan mengenai keselamatan simpang. Data perilaku meliputi konflik dan menghindari manuver. Konflik adalah interksi tiba-tiba yang terjadi untuk menghindari tabrakan sedangkan menghindari manuver adalah perubahan pergerakan karena interaksi dari beberapa pihak. Data dikumpulkan dari rekaman video lokasi simpang yang ditinjau dan dilakukan pencatatan data selama 2 jam. Pengumpulan data dilakukan pada hari kerja dengan kondisi cuaca cerah (Pukul 08.00-18.00).

\section{Data nilai keselamatan}

Studi ini berusaha untuk mengevaluasi keselamatan dalam bentuk nilai sebagai tambahan untuk mengukur keselamatan. Orang-orang yang banyak memiliki pengetahuan tentang pejalan kaki akan memberi nilai sesuai dengan persepsinya terhadap tingkat keselamatan bagi pejalan kaki. Data ini bersifat subjektif dan dapat dikumpulkan dalam jumlah banyak dalam waktu yang singkat.

Data dari tiga jenis pengukuran keselamatan yakni data kecelakaan pejalan kaki, perilaku dan nilai keselamatan dikumpulkan untuk pengembangan model PedISI. Pengembangan model PedISI diawali dengan pengembangan model dari setiap jenis pengukuran keselamatan. Model nilai keselamatan adalah model inti dalam pengembangan model PedISI karena model ini yang mengarah pada pengembangan indeks keselamatan. Meskipun model nilai keselamatan menjadi dasar dalam pengembangan indeks, model perilaku juga memiliki kontribusi terhadap indeks keselamatan.

PedISI dikembangkan menggunakan analisis regresi linier berganda untuk menghubungkan variabel terikat yaitu rata-rata nilai skor keselamatan terhadap angka dari variabel bebas yang mendeskripsikan geometri simpang, fasilitas pejalan kaki dan kondisi lalu lintas. Variabel bebas tersebut merupakan variabel bebas yang signifikan pada model perilaku dan model nilai keselamatan. Analisis dilakukan hanya pada pendekat jalan utama.
Model nilai keselamatan dikembangkan menggunakan model regresi linear berganda karena data nilai keselamatan secara umum mengikuti distribusi normal sedangkan model perilaku dikembangkan menggunakan model regresi Poisson tergeneralisasi karena data perilaku secara umum mengikuti distribusi Poisson. Semua variabel bebas yang signifikan dalam kedua model dipertahankan dan digunakan dalam pengembangan model PedISI. Hasil dari pengembangan model PedISI oleh FHWA dinyatakan dalam persamaan regresi sebagai berikut:

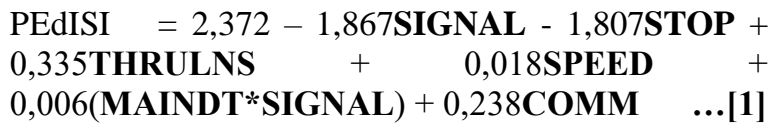

\section{Metodologi}

Metodologi penelitian akan memaparkan tentang penentuan lokasi yang ditinjau, metode pengumpulan data baik data sekunder maupun data primer dan metode pengolahan dan analisis data. Urutan kegiatan yang dilakukan dalam penelitian meliputi:

a. Memilih lokasi penelitian berdasarkan kriteria yang ditentukan sesuai dengan kondisi dan faktorfaktor penting dari simpang bersinyal yang mendasari masalah keselamatan pejalan kaki yang ada di Kota Bandung.

b. Melakukan pengumpulan data. Data yang dikumpulkan adalah sebagai berikut:

\section{- Data kecelakaan}

Data sekunder yang diperoleh dari Satlantas Polrestabes Kota Bandung dalam tiga tahun terakhir (2015-2017).

\section{- Data karakteristik fisik}

Data geoemetrik simpang berupa data primer sedangkan data fasilitas penyeberangan jalan berupa data sekunder yang divalidasi dengan pengamatan langsung di lokasi penelitian. Data karakteristik fisik berupa angka dari variabel-variabel yang berhubungan dalam penilaian tingkat keselamatan bagi pejalan kaki pada penyeberangan jalan di simpang. Variabel-variabel ini akan dianalisis regresi sebagai variabel bebas dalam pengembangan model. Variabel-variabel yang telah teridentifikasi berpotensi memiliki pengaruh secara signifikan terhadap 
keselamatan pejalan kaki di simpang bersinyal Kota Bandung meliputi volume lalu lintas, kecepatan, total jumlah lajur, jumlah lajur belok kanan, jumlah lajur belok kiri, total lebar lajur, lebar median, lebar area penyeberangan, jumlah sinyal lalu lintas, kecepatan 85 persentil dan tipe dominan area jalan

\section{- Data perilaku}

Data primer yang diperoleh melalui pengamatan rekaman video simpang ATCS (Area Traffic Control System) Dinas Perhubungan Kota Bandung. Pengamatan dilakukan selama hari kerja dengan kondisi cuaca cerah. Pengamatan dilakukan mulai pukul 10.00-14.00 WIB. Setiap lokasi penelitian membutuhkan waktu pengamatan selama 2 jam. Hasil dari pengamatan yang dilakukan dengan rekaman video pada setiap lokasi penelitian adalah perilaku pejalan kaki dengan mempertimbangkan interaksinya dengan kendaraan bermotor sehingga dapat diperoleh presentase konflik. Dalam pengembangan model perilaku, data perilaku berupa presentase konflik akan menjadi variabel terikat.

\section{- Data nilai keselamatan}

Data primer yang diperoleh dari survei wawancara. Survei wawancara dilakukan secara langsung kepada responden dengan mengunakan kuisoner dan klip video. Klip video bertujuan agar memungkinkan responden mampu merasakan kecepatan dan volume lalu lintas kondisi aktual serta fitur dari simpang. Survei wawancara ini menggunakan 16 klip video yang masing-masing berdurasi 40 detik. Jumlah responden dalam survei ini adalah 320 responden.

Setiap responden akan memberikan nilai keselamatan dari skala 1 hingga 5 sesuai dengan persepsi mereka terhadap aspek keselamatan. Jika evaluator merasa sangat aman sebagai pejalan kaki dengan kondisi yang ditunjukkan melalui klip video yang diberikan maka evaluator diharuskan member nilai "1" begitupula sebaliknya. Data nilai keselamatan yang diperoleh akan dianalisis untuk perhitungan nilai rata-rata skor keselamatan pada setiap lokasi simpang. Dalam pengembangan model nilai keselamatan, data rata-rata skor nilai keselamatan akan menjadi variabel terikat.

c. Mengembangkan model perilaku

Pengembangan model perilaku dilakukan dengan menggunakan model regresi Poisson tergeneralisasi. Model regresi Poisson tergeneralisasi dapat digunakan baik dalam keadaan underdispersi, equidispersi atau overdispersi. Langkah-langkah untuk memperoleh model regresi Poisson tergeneralisasi terbaik (Listiyani dan Purhadi, 2010) adalah sebagai berikut:

1. Memeriksa hubungan antar variabel

2. Memeriksa model regresi Poisson (uji asumsi equidispersi)

3. Memeriksa kasus overdispersi atau underdispersi.

4. Menentukan model regresi Poisson tergeneralisasi.

d. Mengembangkan model nilai keselamatan

e. Pengembangan model nilai keselamatan dilakukan dengan menggunakan model regresi linier berganda. Model regresi linier berganda adalah hubungan secara linear antara dua atau lebih variabel bebas $\left(X_{1}, X_{2}, \ldots X_{n}\right)$ dengan variabel terikat (Y), apakah masing-masing variabel bebas berhubungan positif atau negatif dan memprediksi nilai dari variabel terikat apabila nilai variabel bebas mengalami kenaikan atau penurunan. Data yang digunakan biasanya berskala interval atau rasio. Dalam penelitian ini, menentukan model regresi linier berganda yang terbaik dengan menggunakan metode backward elimination. Metode backward elimination adalah pembuatan model regresi linier berganda dilakukakan dengan langkah mundur yaitu memasukkan semua variabel bebas (X) untuk diregresikan dengan variabel terikat (Y). Kemudian, variabel bebas (X) dieliminasi satu-persatu dengan melakukan pengujian terhadap parameter- parameternya dengan menggunakan partial $\mathrm{F}$ test.

f. Mengembangkan model PedISI

Model PedISI dikembangkan menggunakan analisis regresi linier berganda untuk menghubungkan nilai keselamatan terhadap angka dari variabel bebas yang mendeskripsikan geometri simpang, fasilitas pejalan kaki dan kondisi lalu lintas yang signifikan pada model perilaku dan model nilai keselamatan. Variabel 
terikat dalam model PedISI adalah rata-rata skor nilai keselamatan karena dasar dari pengembangan model PedISI adalah model nilai keselamatan sedangkan variabel bebasnya adalah variabel yang signifikan pada kedua model. Analisis dilakukan hanya pada pendekat jalan utama.

g. Mengaplikasikan model PedISI yang terbentuk untuk dapat mengetahui nilai PedISI dari simpang bersinyal yg ditinjau.

h. Membandingkan nilai PedISI model yang terbentuk dengan model yang dikembangkan oleh FHWA.

\section{ANalisis dan Pembahasan}

\section{IV.1 Data Kecelakaan Pejalan Kaki dan Penyeberang Jalan Kota Bandung}

Berikut ini adalah hasil analisis data kecelakaan pejalan kaki dan penyeberangan jalan Kota Bandung tahun 2015-2017.

1. Total jumlah kecelakaan berjumlah 421 kecelakaan.

2. Kecelakaan banyak terjadi di ruas dibandingkan dengan di simpang berjumlah 385 kecelakaan.

3. Total jumlah korban kecelakaan berjumlah 532 orang.

4. Tipe korban kecelakaan didominasi oleh ppenyeberang jalan dengan jumlah 471 orang.

5. Tingkat fatalitas yang banyak dialami korban adalah luka ringan berjumlah 460 orang.

6. Korban kecelakaan didominasi oleh wanita dengan jumlah 286 orang.

7. Usia korban kecelakaan didominasi oleh usia produktif yaitu 16-30 tahun dengan jumlah 129 orang.

8. Kejadian kecelakaan banyka terjadi di hari kerja dan pada malam hari.

9. Kendaraan yang sering terlibat kecelakaan dengan pejalan kaki adalah kendaraan beroda dua.

10. Penyebab utama kecelakan pejalan kaki dan penyeberang jalan dikarenakan buruknya fasilitas penyeberangan jalan yang tersedia di simpang.

11. Tipe kecelakaan yang sering terjadi adalah kecelakaan pada lokasi tidak bersinyal berjumlah 140 kecelakaan.

12. Kecelakaan sering terjadi di kawasan komersial dengan fungsi jalan arteri primer dua arah.

\section{IV.2 Data karakterisrik fisik}

Berikut ini adalah data karakteristik fisik yang digunakan untuk pengembangan model PedISI yang tersaji dalam Tabel $\mathbf{1}$ dan $\mathbf{2}$, data volume lalu lintas yang tersaji dalam Tabel 3, data kecepatan dan kecepatan 85 persentil yang tersaji dalam Tabel 4 dan

Tabel 1 Data Karakteristik Simpang (X1-X5)

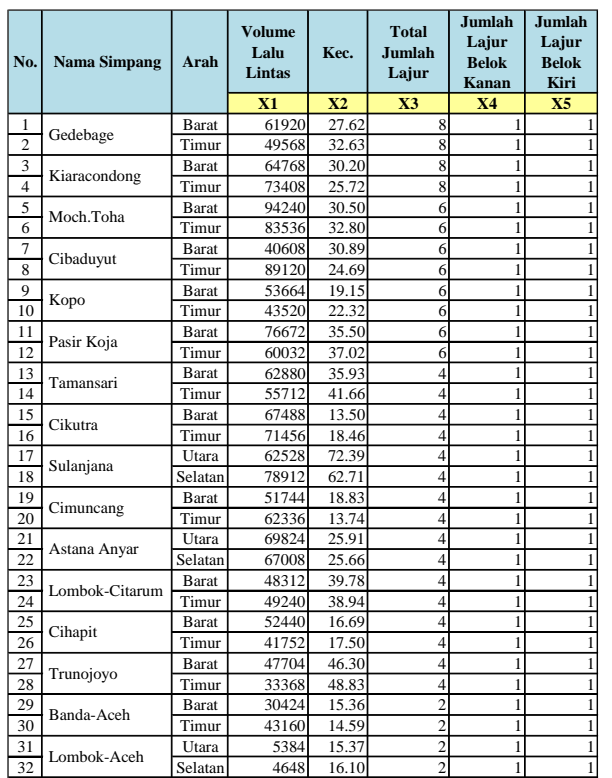

Tabel 2 Data Karakteristik Simpang (X6-X11)

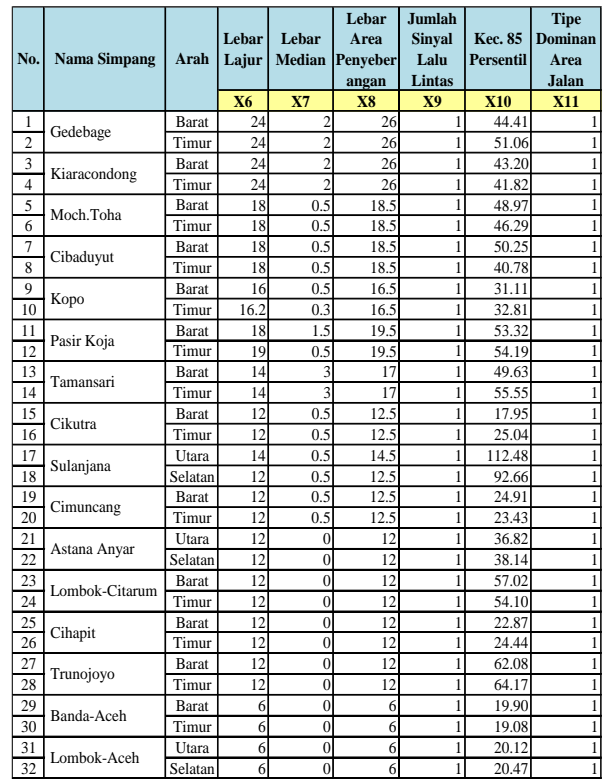

Istiqomah Nurhidayati, Aine Kusumawat, Sri Hendarto 
Tabel 3 Data Volume Lalu Lintas

\begin{tabular}{|c|c|c|c|c|}
\hline No & Nama Simpang & Tipe & Arah & $\begin{array}{c}\begin{array}{c}\text { Volume Lalin } \\
\text { (kend/hari) }\end{array} \\
\end{array}$ \\
\hline 1 & \multirow{2}{*}{ Gedebage } & \multirow{2}{*}{$8 / 2 \mathrm{D}$} & Barat & 61920 \\
\hline 2 & & & Timur & 49568 \\
\hline 3 & \multirow{2}{*}{ Kiaracondong } & \multirow{2}{*}{$8 / 2 \mathrm{D}$} & Barat & 64768 \\
\hline 4 & & & Timur & 73408 \\
\hline 5 & \multirow{2}{*}{ Moch.Toha } & \multirow{2}{*}{$6 / 2 \mathrm{D}$} & Barat & 94240 \\
\hline 6 & & & Timur & 83536 \\
\hline 7 & \multirow{2}{*}{ Cibaduyut } & \multirow{2}{*}{$6 / 2 \mathrm{D}$} & Barat & 40608 \\
\hline 8 & & & Timur & 89120 \\
\hline 9 & \multirow{2}{*}{ Kopo } & \multirow{2}{*}{$6 / 2 \mathrm{D}$} & Barat & 53664 \\
\hline 10 & & & Timur & 43520 \\
\hline 11 & \multirow{2}{*}{ Pasir Koja } & \multirow{2}{*}{$6 / 2 \mathrm{D}$} & Barat & 76672 \\
\hline 12 & & & Timur & 60032 \\
\hline 13 & \multirow{2}{*}{ Tamansari } & \multirow{2}{*}{$4 / 2 \mathrm{D}$} & Barat & 62880 \\
\hline 14 & & & Timur & 55712 \\
\hline 15 & \multirow{2}{*}{ Cikutra } & \multirow{2}{*}{$4 / 2 \mathrm{D}$} & Barat & 67488 \\
\hline 16 & & & Timur & 71456 \\
\hline 17 & \multirow{2}{*}{ Sulanjana } & \multirow{2}{*}{$4 / 2 \mathrm{D}$} & Utara & 62528 \\
\hline 18 & & & Selatan & 78912 \\
\hline 19 & \multirow{2}{*}{ Cimuncang } & \multirow{2}{*}{$4 / 2 \mathrm{D}$} & Barat & 51744 \\
\hline 20 & & & Timur & 62336 \\
\hline \multirow{2}{*}{$\frac{21}{22}$} & \multirow{2}{*}{ Astana Anyar } & \multirow{2}{*}{$4 / 2$ UD } & Utara & 69824 \\
\hline & & & Selatan & 67008 \\
\hline \multirow{2}{*}{$\frac{23}{24}$} & \multirow{2}{*}{ Lombok-Citarum } & \multirow{2}{*}{$4 / 2$ UD } & Barat & 48312 \\
\hline & & & Timur & 49240 \\
\hline \multirow{2}{*}{$\frac{25}{26}$} & \multirow{2}{*}{ Cihapit } & \multirow{2}{*}{$4 / 2$ UD } & Barat & 52440 \\
\hline & & & Timur & 41752 \\
\hline \multirow{3}{*}{$\frac{27}{28}$} & & & Barat & 47704 \\
\hline & Trunojoyo & $4 / 2$ UD & Timur & 33368 \\
\hline & Band $-A$ ceh & $2 / 2 \mathrm{WD}$ & Barat & 30424 \\
\hline 30 & Banda-Aceh & $2 / 2 \mathrm{UD}$ & Timur & 43160 \\
\hline 31 & & & Utara & 5384 \\
\hline 32 & Lombok-Aceh & $2 / 2 \mathrm{UD}$ & Selatan & 4648 \\
\hline
\end{tabular}

Berdasarkan Tabel 3, rata-rata volume lalu lintas pada simpang sebesar $56168 \mathrm{kend} / \mathrm{hari}$ dengan standard deviasi sebesar 20391,4. Simpang yang memiliki volume lalu lintas tertinggi adalah Simpang Mochammad Toha (arah barat) sedangkan simpang yang memiliki volume lalu lintas terendah adalah Simpang Lombok-Aceh (arah selatan). Besarnya volume lalu lintas sangat dipengaruhi oleh jumlah lajur, banyaknya pusat kegiatan yang ada di sekitar lokasi simpang sehingga banyak pergerakan di sekitar terutama kendaraan yang berlalu lintas. Semakin banyak jumlah lajur dan pusat kegiatan di sekitar simpang maka semakin besar pula volume lalu lintas. Dalam pengembangan model, besarnya volume lalu lintas yang dimasukkan menggunakan satuan kend/hari dalam ribuan.

\section{Tabel 4 Data Kecepatan}

\begin{tabular}{|r|l|c|c|r|}
\hline No & \multirow{2}{*}{ Nama Simpang } & Tipe & Arah & $\begin{array}{c}\text { V } \\
(\mathbf{k m} / \mathbf{j a m})\end{array}$ \\
\hline 1 & \multirow{2}{*}{ Gedebage } & \multirow{2}{*}{$8 / 2 \mathrm{D}$} & Barat & 27.62 \\
\cline { 1 - 3 } & & Timur & 32.63 \\
\hline 3 & \multirow{2}{*}{ Kiaracondong } & \multirow{2}{*}{$8 / 2 \mathrm{D}$} & Barat & 30.20 \\
\cline { 1 - 1 } 4 & & Timur & 25.72 \\
\hline
\end{tabular}

Tabel 4 Data Kecepatan (Lanjutan)

\begin{tabular}{|c|c|c|c|c|}
\hline No & Nama Simpang & Tipe & Arah & $\begin{array}{c}\mathrm{V} \\
(\mathrm{km} / \mathrm{jam})\end{array}$ \\
\hline 5 & \multirow{2}{*}{ Moch.Toha } & \multirow{2}{*}{$6 / 2 \mathrm{D}$} & Barat & 30.50 \\
\hline 6 & & & Timur & 32.80 \\
\hline 7 & \multirow{2}{*}{ Cibaduyut } & \multirow{2}{*}{$6 / 2 \mathrm{D}$} & Barat & 30.89 \\
\hline 8 & & & Timur & 24.69 \\
\hline 9 & \multirow{2}{*}{ Коро } & \multirow{2}{*}{$6 / 2 \mathrm{D}$} & Barat & 19.15 \\
\hline 10 & & & Timur & 22.32 \\
\hline 11 & \multirow{2}{*}{ Pasir Koja } & \multirow{2}{*}{$6 / 2 \mathrm{D}$} & Barat & 35.50 \\
\hline 12 & & & Timur & 37.02 \\
\hline 13 & \multirow{2}{*}{ Tamansari } & \multirow{2}{*}{$4 / 2 \mathrm{D}$} & Barat & 35.93 \\
\hline 14 & & & Timur & 41.66 \\
\hline 15 & \multirow{2}{*}{ Cikutra } & \multirow{2}{*}{$4 / 2 \mathrm{D}$} & Barat & 13.50 \\
\hline 16 & & & Timur & 18.46 \\
\hline 17 & \multirow{2}{*}{ Sulanjana } & \multirow{2}{*}{$4 / 2 \mathrm{D}$} & Utara & 72.39 \\
\hline 18 & & & Selatan & 62.71 \\
\hline 19 & \multirow{2}{*}{ Cimuncang } & \multirow{2}{*}{$4 / 2 \mathrm{D}$} & Barat & 18.83 \\
\hline 20 & & & Timur & 13.74 \\
\hline 21 & \multirow{2}{*}{ Astana Anyar } & \multirow{2}{*}{$4 / 2$ UD } & Utara & 25.91 \\
\hline 22 & & & Selatan & 25.66 \\
\hline 23 & \multirow{2}{*}{ Lombok-Citarum } & \multirow{2}{*}{$4 / 2$ UD } & Barat & 39.78 \\
\hline 24 & & & Timur & 38.94 \\
\hline 25 & \multirow{2}{*}{ Cihapit } & \multirow{2}{*}{$4 / 2 \mathrm{UD}$} & Barat & 16.69 \\
\hline 26 & & & Timur & 17.50 \\
\hline 27 & \multirow{2}{*}{ Trunojoyo } & \multirow{2}{*}{$4 / 2 \mathrm{UD}$} & Barat & 46.30 \\
\hline 28 & & & Timur & 48.83 \\
\hline 29 & \multirow{2}{*}{ Banda-Aceh } & \multirow{2}{*}{$2 / 2 \mathrm{UD}$} & Barat & 15.36 \\
\hline 30 & & & Timur & 14.59 \\
\hline 31 & \multirow{2}{*}{ Lombok-Aceh } & \multirow{2}{*}{$2 / 2 \mathrm{UD}$} & Utara & 15.37 \\
\hline 32 & & & Selatan & 16.10 \\
\hline
\end{tabular}

Berdasarkan Tabel 4, rata-rata kecepatan kendaraan pada simpang sebesar 29,60 km/jam dengan standar deviasi sebesar 14,1. Kecepatan ratarata tertinggi berada di Simpang Sulanjana (utara) sedangkan kecepatan rata-rata terendah berada di Simpang Cikutra (barat). Besarnya kecepatan sangat dipengaruhi oleh banyaknya volume lalu lintas dan jumlah pejalan kaki dan penyeberang jalan serta panjang segmen jalan antara zebra cross. Besarnya kecepatan berbanding terbaik dengan volume lalu lintas. Banyaknya jumlah pejalan kaki dan penyeberang jalan dengan volume lalu lintas yang tinggi saat lampu hijau, dapat memicu meningkatnya interaksi antara keduanya sehingga kecepatan kendaraan dapat menurun karena kendaraan berusaha menghindar atau kendaraan terjebak.

Tabel 5 Kecepatan 85 Persentil

\begin{tabular}{|c|l|c|c|r|}
\hline No & \multirow{2}{*}{ Nama Simpang } & Tipe & Arah & $\begin{array}{c}\text { V 85 Persentil } \\
(\mathbf{k m} / \mathbf{j a m})\end{array}$ \\
\hline 1 & \multirow{2}{*}{$\begin{array}{l}\text { Gedebage } \\
2\end{array}$} & \multirow{2}{*}{$8 / 2 \mathrm{D}$} & Barat & 44.41 \\
\cline { 4 - 5 } & \multirow{2}{*}{3} & Timur & 51.06 \\
\hline 4 & & \multirow{2}{*}{ Kiaracondong } & Barat & 43.20 \\
\cline { 1 - 3 } & & Timur & 41.82 \\
\hline
\end{tabular}

Istiqomah Nurhidayati, Aine Kusumawat, Sri Hendarto 
Tabel 5 Kecepatan 85 Persentil (Lanjutan)

\begin{tabular}{|c|c|c|c|c|}
\hline No & Nama Simpang & Tipe & Arah & \begin{tabular}{|c|}
$\begin{array}{c}\text { V } 85 \text { Persentil } \\
(\mathrm{km} / \mathrm{jam})\end{array}$ \\
\end{tabular} \\
\hline 5 & \multirow{2}{*}{ Moch.Toha } & \multirow{2}{*}{$6 / 2 \mathrm{D}$} & Barat & 48.97 \\
\hline 6 & & & Timur & 46.29 \\
\hline 7 & \multirow{2}{*}{ Cibaduyut } & \multirow{2}{*}{$6 / 2 \mathrm{D}$} & Barat & 50.25 \\
\hline 8 & & & Timur & 40.78 \\
\hline 9 & \multirow{2}{*}{ Kopo } & \multirow{2}{*}{$6 / 2 \mathrm{D}$} & Barat & 31.11 \\
\hline 10 & & & Timur & 32.81 \\
\hline 11 & \multirow{2}{*}{ Pasir Koja } & \multirow{2}{*}{$6 / 2 \mathrm{D}$} & Barat & 53.32 \\
\hline 12 & & & Timur & 54.19 \\
\hline 13 & \multirow{2}{*}{ Tamansari } & \multirow{2}{*}{$4 / 2 \mathrm{D}$} & Barat & 49.63 \\
\hline 14 & & & Timur & 55.55 \\
\hline 15 & \multirow{2}{*}{ Cikutra } & \multirow{2}{*}{$4 / 2 \mathrm{D}$} & Barat & 17.95 \\
\hline 16 & & & Timur & 25.04 \\
\hline 17 & \multirow{2}{*}{ Sulanjana } & \multirow{2}{*}{$4 / 2 \mathrm{D}$} & Utara & 112.48 \\
\hline 18 & & & Selatan & 92.66 \\
\hline 19 & \multirow{2}{*}{ Cimuncang } & \multirow{2}{*}{$4 / 2 \mathrm{D}$} & Barat & 24.91 \\
\hline 20 & & & Timur & 23.43 \\
\hline 21 & \multirow{2}{*}{ Astana Anyar } & \multirow{2}{*}{$4 / 2 \mathrm{UD}$} & Utara & 36.82 \\
\hline 22 & & & Selatan & 38.14 \\
\hline 23 & \multirow{2}{*}{ Lombok-Citarum } & \multirow{2}{*}{$4 / 2 \mathrm{UD}$} & Barat & 57.02 \\
\hline 24 & & & Timur & 54.10 \\
\hline 25 & \multirow{2}{*}{ Cihapit } & \multirow{2}{*}{$4 / 2 \mathrm{UD}$} & Barat & 22.87 \\
\hline 26 & & & Timur & 24.44 \\
\hline 27 & \multirow{2}{*}{ Trunojoyo } & \multirow{2}{*}{$4 / 2$ UD } & Barat & 62.08 \\
\hline 28 & & & Timur & 64.17 \\
\hline 29 & \multirow{2}{*}{ Banda-Aceh } & \multirow{2}{*}{$2 / 2$ UD } & Barat & 19.90 \\
\hline 30 & & & Timur & 19.08 \\
\hline 31 & \multirow{2}{*}{ Lombok-Aceh } & \multirow{2}{*}{$2 / 2 \mathrm{UD}$} & Utara & 20.12 \\
\hline 32 & & & \begin{tabular}{|l|} 
Selatan \\
\end{tabular} & 20.47 \\
\hline
\end{tabular}

Berdasarkan Tabel 5, rata-rata kecepatan 85 persentil keseluruhan simpang sebesar 43,10 km/jam dengan standard deviasi sebesar 21,16. Angka kecepatan rata-rata seluruh simpang yang diperoleh dari pengukuran langsung di lapangan masih berada di bawah standar keamanan berdasarkan perhitungan kecepatan 85 persentil sehingga kecepatan kendaraan dapat dinyatakan aman.

\section{IV.3 Data Perilaku}

Dari pengamatan yang telah dilakukan diperoleh jumlah dari setiap jenis interaksi untuk mengetahui besarnya presentase konflik pada setiap simpang yang tersaji dalam Tabel 6. Jumlah interaksi yang terjadi di simpang antara pejalan kaki dan pengguna kendaraan bermotor sangat dipengaruhi oleh jumlah dan karakteristik dari pejalan kaki bukan hanya dari banyak jumlah lajur pada simpang. Hal ini karena interaksi merupakan kejadian acak dan bisa saja dalam waktu pengamatan yang ditentukan tidak terjadi interaksi sama sekali. Semakin banyak jumlah pejalan kaki di suatu simpang maka jumlah interaksi yang terjadi semakin besar.
Tabel 6 Data Interaksi Normal dan Abnormal

\begin{tabular}{|c|c|c|c|c|c|c|c|c|}
\hline \multirow{3}{*}{ No } & \multirow{3}{*}{ Simpang } & \multirow{3}{*}{ Tipe } & \multicolumn{5}{|c|}{ Jenis Interaksi } & \multirow{3}{*}{\begin{tabular}{|c|} 
Jumlah \\
Interaksi \\
Abnormal
\end{tabular}} \\
\hline & & & \multirow{2}{*}{ None } & \multirow{2}{*}{ Normal } & \multicolumn{3}{|c|}{\begin{tabular}{|c|} 
Abnormal \\
\end{tabular}} & \\
\hline & & & & & \begin{tabular}{|l|} 
Yield \\
\end{tabular} & Abort & Hurry & \\
\hline 1 & Gedebage & $8 / 2 \mathrm{D}$ & 0 & 61 & \begin{tabular}{|l|}
17 \\
\end{tabular} & 14 & 13 & 44 \\
\hline 2 & \begin{tabular}{|l|} 
Kiaracondong \\
\end{tabular} & $8 / 2 \mathrm{D}$ & 0 & 97 & 17 & 0 & 10 & 27 \\
\hline 3 & \begin{tabular}{|l|} 
Moch.Toha \\
\end{tabular} & $6 / 2 \mathrm{D}$ & 0 & 72 & 8 & 2 & 4 & 14 \\
\hline 4 & Cibaduyut & $6 / 2 \mathrm{D}$ & 0 & 135 & 14 & 7 & 15 & 36 \\
\hline 5 & Kopo & $6 / 2 \mathrm{D}$ & 0 & 99 & 17 & 16 & 16 & 49 \\
\hline 6 & Pasir Koja & $6 / 2 \mathrm{D}$ & 0 & 212 & 14 & 6 & 12 & 32 \\
\hline 7 & Tamansari & $4 / 2 \mathrm{D}$ & 0 & 89 & 6 & 0 & 6 & 12 \\
\hline 8 & Cikutra & $4 / 2 \mathrm{D}$ & 0 & 95 & 4 & 1 & 10 & 15 \\
\hline 9 & Sulanjana & $4 / 2 \mathrm{D}$ & 0 & 109 & 4 & 2 & 8 & 14 \\
\hline 10 & Cimuncang & $4 / 2 \mathrm{D}$ & 0 & 43 & 9 & 2 & 6 & 17 \\
\hline 11 & \begin{tabular}{|l} 
Astana Anyar \\
\end{tabular} & $4 / 2 \mathrm{UD}$ & 0 & 64 & 20 & 4 & 23 & 47 \\
\hline 12 & Lombok-Citarum & $4 / 2 \mathrm{UD}$ & 0 & 59 & 20 & 5 & 14 & 39 \\
\hline 13 & Trunojoyo & $4 / 2 \mathrm{UD}$ & 0 & 32 & 3 & 0 & 5 & 8 \\
\hline 14 & \begin{tabular}{|l|} 
Cihapit \\
\end{tabular} & $4 / 2$ UD & 0 & 51 & 11 & 5 & 9 & 25 \\
\hline 15 & Banda-Aceh & $2 / 2 \mathrm{UD}$ & 0 & 13 & 4 & 0 & 2 & 6 \\
\hline 16 & \begin{tabular}{|l|} 
Lombok-Aceh \\
\end{tabular} & $2 / 2 \mathrm{UD}$ & 0 & 22 & 6 & 2 & 6 & 14 \\
\hline
\end{tabular}

Berdasarkan data yang tersaji dalam Tabel 6, jumlah interaksi normal yang paling banyak terjadi di Simpang Pasir Koja sedangkan simpang yang memiliki jumlah interaksi normal dan abnormal paling sedikit adalah Simpang Banda-Aceh. Dalam penelitian ini, total jumlah interaksi pejalan kaki yang berhasil diamati adalah 1652 peristiwa dalam waktu pengamatan lebih dari 25 jam. Dalam 1 jam, rata-rata interaksi yang terjadi adalah 31,77 interaksi.

Tabel 7 Data Presentase Konflik

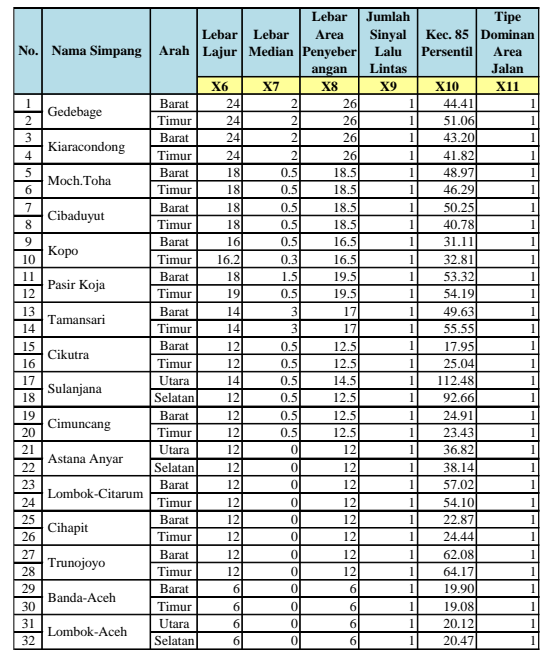

Berdasarkan Tabel 7, rata-rata dari besarnya presentase konflik setiap simpang adalah menunjukkan bahwa Simpang Astana Anyar arah utara merupakan simpang dengan presentase konflik tertinggi sedangkan Simpang Tamansari arah barat merupakan simpang dengan presentase konflik terendah. Jumlah presentase konflik yang tinggi menandakan bahwa pada simpang sering terjadi interaksi antara pejalan kaki atau penyeberang jalan

Istiqomah Nurhidayati, Aine Kusumawat, Sri Hendarto 
dengan kendaraan bermotor begitupula sebaliknya. Semakin besarnya interaksi kemungkinan untuk terjadinya kecelakaan juga semakin tinggi.

\section{IV.4 Data nilai keselamatan}

Penilaian keselamatan didasarkan pada fasilitas yang tersedia dan kondisi lalu lintas simpang. Pada penelitian ini, jumlah responden sebanyak 320 orang. Jumlah responden ditentukan berdasarkan survei pendahuluan mengenai jumlah pejalan kaki dan penyeberang jalan di Kota Bandung. Perhitungan populasi pejalan kaki dan penyeberang jalan dilakukan melalui rekaman video simpang ATCS Kota Bandung.

Selain data nilai keselamatan, dari hasil survei wawancara juga dapat diketahui karakteristik responden. Karakteristik dari responden sangat berpengaruh terhadap persepsi dalam menilai keselamatan pada simpang. Karakteristik responden dalam penelitian ini adalah sebagai berikut:

1. Responden didominasi oleh usia produktif yaitu 16-30 tahun berjumlah 112 responden.

2. Responden laki-laki, jumlahnya jauh lebih banyak dibandingkan dengan responden perempuaan.

3. Jenis pekerjaan dari responden sangat beragam namun didominasi oleh mahasiswa atau pelajar berjumlah 66 responden.

Nilai keselamatan akan digunakan untuk menghitung rata-rata nilai keselamatan untuk setiap pendekat pada simpang. Rata-rata nilai keselamatan merupakan variabel terikat dalam pengembangan model nilai keselamatan. Model nilai keselamatan merupakan dasar dari model PedISI sehingga persepsi orang dalam menilai tingkat keselamatan simpang bagi pejalan kaki sangat penting.

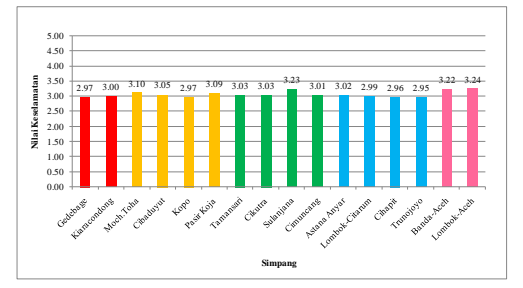

Gambar 2 Distribusi Nilai Keselamatan

Berdasarkan Gambar 2 dapat dilihat bahwa dari skala 1 sampai 5 yang diberikan, nilai keselamatan bagi pejalan kaki yang diberikan oleh responden ratarata adalah 3,05 yang menunjukkan keseluruhan simpang bersinyal yang ditinjau dalam penelitian ini memiliki tingkat keselamatan yang cukup. Hasil ini menunjukkan keseragaman persepsi responden dalam menilai tingkat keselamatan simpang bagi pejalan kaki di simpang karena tidak terdapat variasi nilai keselamatan sedangkan tipe simpang berbeda dengan kondisi lalu lintas dan fasilitas penyeberangan yang tersedia pun berbeda.

Keseragaman ini terjadi dikarenakan setiap responden tidak menilai seluruh tipe simpang namun hanya beberapa saja sehingga tidak bisa membedakan antara simpang yg satu dan yang lainnya. Pada saat survei, setiap responden hanya menilai 5 simpang. Selain itu, penyebab keseragaman data ini adalah durasi video yang mungki terlalu singkat dan pertanyaaan yang diberikan kepada responden melalui kuisoner kurang lebih spesifik.

\section{IV.5 Pengembangan Model}

Proses pengembangan model ini dimulai dari pengembangan model perilaku dan model nilai keselamatan. Variabel bebas yang signifikan pada kedua model tersebut akan digunakan sebagai variabel bebas dalam pengembangan model PedISI untuk simpang bersinyal Kota Bandung. Setelah model PedISI terbentuk, dilakukan pengaplikasian model untuk mengetahui nilai PedISI atau indeks keselamatan simpang dari setiap lokasi penelitian. Setelah itu, nilai PedISI dari model yang terbentuk dibandingkan dengan nilai PedISI dari model yang telah dikembangkan oleh FHWA.

\section{IV.5.1 Model Perilaku}

Pengembangan model perilaku dilakukan dengan menggunakan model regresi Poisson tergeneralisasi.

Tabel 9 Uji Multikolinieritas

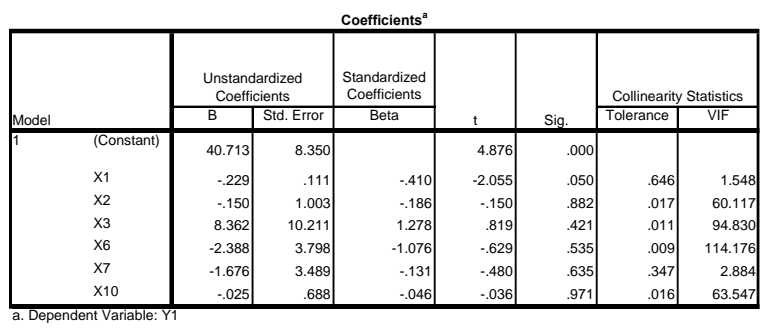

Berdasarkan hasil uji multikolinieritas pada Tabel 9, dapat dilihat bahwa model regresi memiliki masalah multikoliniertas karena variabel X2, X3, X6 dan X6 tidak memenuhi kriteria uji yaitu nilai VIF lebih dari 10 dan nilai tolerance kurang dari 0,1 . Guna menghilangkan masalah multikolinieritas pada model 
regresi,salah satu cara sederhana yang dapat dilakukan adalah variabel bebas yang tidak sesuai dengan kriteria uji dihilangkan dalam model.

Tabel 10 Uji Asumsi Equidispersi

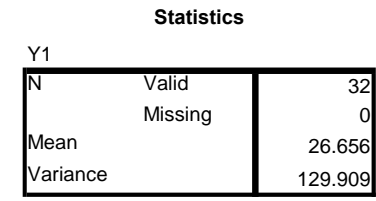

Berdasarkan hasil uji asumsi equidispersi pada Tabel 10, dapat dilihat bahwa asumsi tidak terpenuhi. Dalam model regresi Poisson tergeneralalisasi, apabila uji asumsi equidispersi tidak terpenuhi tidak menjadi masalah.

Tabel 11 Uji Kasus Data

\begin{tabular}{|c|c|c|c|c|c|c|c|}
\hline \multirow[b]{3}{*}{ Parameter } & & & Paramete & stimates & & & \\
\hline & \multirow[b]{2}{*}{ B } & \multirow[b]{2}{*}{ Std. Error } & \multicolumn{2}{|c|}{ Interval } & \multicolumn{3}{|c|}{ Hypothesis Test } \\
\hline & & & Lower & Upper & $\begin{array}{l}\text { Wald Chi- } \\
\text { Square }\end{array}$ & df & Sig. \\
\hline (Intercept) & 3.358 & .446 & 2.483 & 4.232 & 56.627 & 1 & .000 \\
\hline$x_{1}$ & .001 & .009 & -.016 & .018 & .018 & 1 & .893 \\
\hline x7 & -.448 & .143 & -.727 & -.168 & 9.840 & 1 & .002 \\
\hline (Scale) & $1^{a}$ & & & & & & \\
\hline
\end{tabular}

Berdasarkan hasil uji pada Tabel 11, dapat dilihat bahwa data mengalami overdispersi karena besarnya nilai Pearson Chi Square dibagi df bernilai lebih dari nol. Dengan kondisi data yang mengalami overdispersi, tidak menjadi masalah karena model regresi Poisson tergeneralisasi dapat digunakan baik dalam kasus overdispersi atau underdispersi.

Metode backward elimination digunakan untuk memilih model terbaik. Metode backward elimination adalah pemodelan regresi dengan menghilangkan variabel yang tidak signifikan satu per satu dari model hingga diperoleh model yang seluruh variabelnya signifkan. Berikut ini adalah hasil model regresi Poisson tergeneralisasi dengan metode backward elimination yang tersaji dalam Tabel 12.

Tabel 12 Hasil Model Perilaku

\begin{tabular}{|c|c|c|c|c|c|c|c|}
\hline \multirow[b]{3}{*}{ Parameter } & & & Paramete & stimates & & & \\
\hline & \multirow[b]{2}{*}{ B } & \multirow[b]{2}{*}{ Std. Error } & \multicolumn{2}{|c|}{$\begin{array}{l}95 \% \text { Wald Confidence } \\
\text { Interval }\end{array}$} & \multicolumn{3}{|c|}{ Hypothesis Test } \\
\hline & & & Lower & Upper & Square & df & Sig. \\
\hline & 3.416 & .105 & 3.210 & 3.623 & 1050.656 & 1 & 0.000 \\
\hline$x 7$ & -.438 & .124 & -.680 & -.196 & 12.574 & 1 & .000 \\
\hline (Scale) & $1^{\mathrm{a}}$ & & & & & & \\
\hline
\end{tabular}

Berdasarkan hasil model pada Tabel 12, variabel bebas yang signifikan terhadap model dengan $p$-value $<0,05$ tetap hanya variabel X7. Sesuai dengan tahapan regresi dengan metode backward eliminiation, apabila seluruh variabel bebas dalam model sudah memiliki $p$-value $<0,05$ maka tahapan pemodelan dihentikan dan model ini menjadi model terbaik yang dipilih. Dari hasil pengembangan model perilaku, variabel bebas yang signifikan terhadap model adalah X7 (lebar median). Variabel ini akan dipertahankan dalam pengembangan model PedISI.

\section{IV.6 Model Nilai Keselamatan}

Pengembangan model nilai keselamatan dilakukan dengan menggunakan model regresi linier berganda. Pemilihan model regresi linier berganda yang terbaik dalam penelitian ini menggunakan metode backward elimination. Variabel bebas yang signifikan dalam model nilai keselamatan terbaik akan dipertahankan dalam pengembangan model PedISI.

\section{Tabel 13 Uji Korelasi}

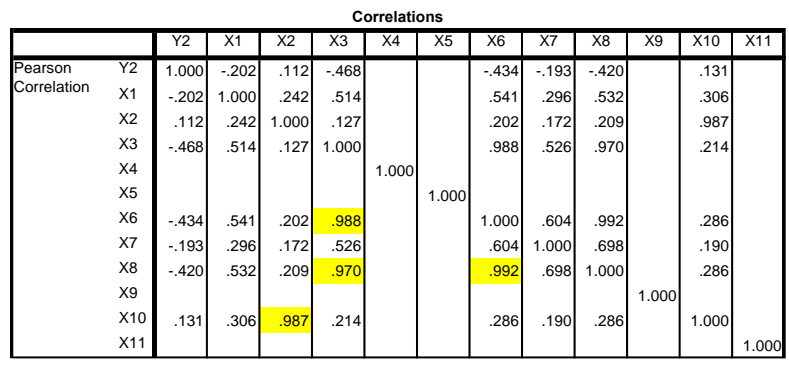

Berdasarkan hasil uji korelasi pada Tabel 13 dapat dianalisis hubungan antara variabel terikat dengan setiap variabel bebas. Dalam model regresi linier berganda, hubungan korelasi antara variabel terikat dan variabel bebas harus tinggi sedangkan korelasi antara variabel bebas harus rendah. Oleh karena itu, sesuai dengan hasil uji korelasi diatas ada lima variabel bebas yang memiliki korelasi sangat tinggi yaitu X2, X3, X6, X8 dan X10. Diantara kelima variabel bebas ini, variabel bebas $\mathrm{X} 3$ tetap dipertahankan dalam model karena memiliki korelasi paling tinggi dengan variabel terikat Y1 sebesar 0,468 sedangkan variabel bebas X6 dan X8 dihilangkan dari model karena kedua variabel tersebut berkorelasi tinggi dengan X3. Selain itu, salah satu diantara variabel X2 dan X10 juga harus dihilangkan dalam model karena keduanya memiliki korelasi yang tinggi.

Tabel 14 Hasil Model Nilai Keselamatan 


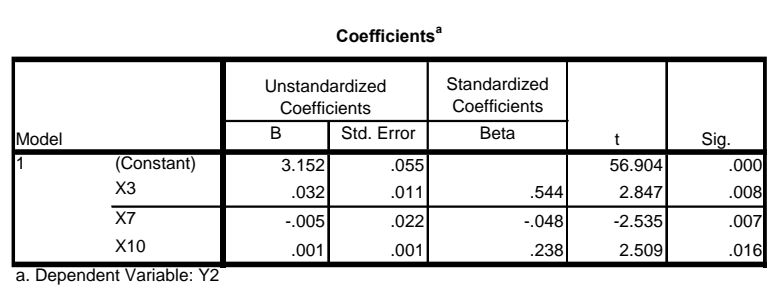

Berdasarkan hasil regresi linier berganda pada Tabel 14, variabel bebas dalam model seluruhnya signifikan terhadap model karena nilai sig $>\mathrm{a}=0,05$. Variabel bebas yang signifikan adalah X3, X7 dan $\mathrm{X} 10$. Sesuai dengan tahapan regresi dengan metode backward eliminiation, apabila seluruh variabel bebas dalam model signifikan maka eliminasi dihentikan dan model pada tahap ini adalah model regresi linier berganda yang terpilih. Dari hasil pengembangan model nilai keselamatan, variabel bebas yang signifikan terhadap model adalah X3 (total jumlah lajur), X7 (lebar median) dan X10 (kecepatan 85 persentil) dengan besar koefisien korelasi determinasi sebesar 0,525. Variabel bebas ini akan dipertahankan dalam pengembangan model PedISI.

\section{IV.7 Model PedISI untuk Simpang Bersinyal Kota Bandung}

Sebelum dilakukan pengembangan model PedISI, dilakukan pengembangan model perilaku dan model nilai keselamatan. Variabel bebas yang signifikan di dalam kedua model akan tetap dipertahankan dalam membangun model PedISI. Berdasarkan hasil dari pengembangan model perilaku dan model nilai keselamatan, variabel bebas yang digunakan dalam membuat model PedISI untuk Simpang Bersinyal Kota Bandung adalah Total Jumlah Lajur (X3), Lebar Median (X7) dan Kecepatan 85 Persentil (X10) sedangkan variabel terikatnya adalah Ratarata Nilai Skor Keselamatan (Y2).

Tabel 15 Hasil Model PedISI

\begin{tabular}{|c|c|c|c|c|c|}
\hline \multicolumn{6}{|c|}{ Coefficients $^{\mathrm{a}}$} \\
\hline \multirow[b]{2}{*}{ Model } & \multicolumn{2}{|c|}{$\begin{array}{l}\text { Unstandardized } \\
\text { Coefficients }\end{array}$} & \multirow{2}{*}{$\begin{array}{c}\text { Standardized } \\
\text { Coefficients }\end{array}$} & \multirow[b]{2}{*}{$t$} & \multirow[b]{2}{*}{ Sig. } \\
\hline & \begin{tabular}{l|l|}
$\mathrm{B}$ \\
\end{tabular} & Std. Error & & & \\
\hline (Constant) & 3.152 & .055 & & 56.904 & .000 \\
\hline $\mathrm{x} 3$ & .032 & .011 & .544 & 2.847 & .008 \\
\hline$\overline{\mathrm{X} 7}$ & -.005 & .022 & -.048 & -2.535 & .007 \\
\hline $\mathrm{X} 10$ & .001 & .001 & .238 & 2.509 & .016 \\
\hline
\end{tabular}

Setelah dilakukan analisis regresi linier berganda, hasil dari pengembangan model PedISI untuk Simpang Bersinyal Kota Bandung dinyatakan dalam persamaan regresi sebagai berikut:

\section{PedISI $=3,184+0,032$ THRULNS 0,005 MEDIAN $+0,001$ SPEED85 $^{\text {th }} \quad \ldots[2]$}

Berdasarkan persamaan [2], variabel bebas yang signifikan dalam model adalah total jumlah lajur (X3), lebar median (X7) dan kecepatan 85 persentil (X10). Penjelasan mengenai masing-masing variabel bebas dalam model sebagai berikut:

\section{Total Jumlah Lajur (X3)}

Meningkatnya jumlah lajur dapat meningkatkan potensi kecelakaan pada pejalan kaki karena interaksi yang terjadi antara pejalan kaki dan kendaraan yang datang akan semakin lama, jarak yang harus ditempuh untuk menyeberang semakin jauh dan membutuhkan waktu yang semakin lama.

\section{Lebar Median (X7)}

Keberadaan median dapat mengurangi konflik yang terjadi antara pejalan kaki dengan kendaraan bermotor karena median dapat menjadi lapak tunggu bagi pejalan kaki untuk berhenti sementara pejalan kaki dalam melakukan penyeberangan sambil menunggu kesempatan melakukan penyeberangan berikutnya. .

\section{Kecepatan 85 Persentil (X10)}

Kecepatan 85 persentil adalah kecepatan lalu lintas dimana $85 \%$ dari pengemudi mengemudikan kendaraannya di jalan tanpa dipengaruhi oleh kecepatan lalu lintas yang lebih rendah atau cuaca yang buruk (Abraham, 2001) dan menandakan bahwa $85 \%$ kendaraaan menggunakan kecepatan dibawah dari nilai kecepatan 85 persentil. Jarak berhenti untuk kendaraan meningkat seiring dengan meningkatnya fungsi kecepatan kendaraan. Sebagai tambahan, kemungkinan cedera fatal pada pejalan kaki juga meningkat pada tabrakan pejalan kaki dan kendaraan bermotor dengan kecepatan tinggi.

Perbedaan yang signifikan terletak pada variabel bebas yang digunakan dalam model karena karakteristik simpang dan kondisi lalu lintas yang berbeda. Model PedISI FHWA dikembangkan untuk dapat digunakan pada simpang bersinyal dan tidak bersinyal sedangkan model PedISI yang dikembangkan dalam penelitian ini hanya dapat digunakan untuk simpang bersinyal.

Dengan menggunakan model PedISI yang terbentuk, dapat dilakukan perhitungan nilai PedISI untuk setiap lokasi simpang yang ditinjau. Nilai

Istiqomah Nurhidayati, Aine Kusumawat, Sri Hendarto 
PedISI pada suatu simpang merupakan nilai rata-rata dari masing-masing pendekat di simpang tersebut.

Tabel 16 Perhitungan Nilai PedISI

\begin{tabular}{|c|c|c|c|c|c|c|c|}
\hline \multirow[t]{2}{*}{ No. } & \multirow[t]{2}{*}{ Nama Simpang } & \multirow[t]{2}{*}{ Arah } & $\begin{array}{c}\text { Total } \\
\text { Jumlah } \\
\text { Lajur }\end{array}$ & $\begin{array}{c}\text { Lebar } \\
\text { Median }\end{array}$ & \begin{tabular}{|c|} 
Kec. 85 \\
Persentil
\end{tabular} & \multirow[t]{2}{*}{$\begin{array}{c}\text { Nilai } \\
\text { PedISI }\end{array}$} & \multirow[t]{2}{*}{$\begin{array}{c}\text { Nilai } \\
\text { PedISI } \\
\text { FHWA }\end{array}$} \\
\hline & & & X3 & $\mathrm{X} 7$ & X10 & & \\
\hline 1 & \multirow{2}{*}{ Gedebage } & Barat & 8 & 2 & 44.41 & 3.45 & 5.79 \\
\hline 2 & & Timur & 8 & 2 & 51.06 & 3.45 & 5.88 \\
\hline 3 & \multirow{2}{*}{ Kiaracondong } & Barat & 8 & 2 & 43.2 & 3.44 & 5.83 \\
\hline 4 & & Timur & 8 & 2 & 41.82 & 3.44 & 5.75 \\
\hline 5 & \multirow{2}{*}{ Moch.Toha } & Barat & 6 & 0.5 & 48.97 & 3.40 & 5.17 \\
\hline 6 & & Timur & 6 & 0.5 & 46.29 & 3.39 & 5.21 \\
\hline 7 & \multirow{2}{*}{ Cibaduyut } & Barat & 6 & 0.5 & 50.25 & 3.40 & 5.18 \\
\hline 8 & & Timur & 6 & 0.5 & 40.78 & 3.39 & 5.06 \\
\hline 9 & \multirow{2}{*}{ Kopo } & Barat & 6 & 0.5 & 31.11 & 3.38 & 4.96 \\
\hline 10 & & Timur & 6 & 0.3 & 32.81 & 3.38 & 5.02 \\
\hline 11 & \multirow{2}{*}{ Pasir Koja } & Barat & 6 & 1.5 & 53.32 & 3.40 & 5.26 \\
\hline 12 & & Timur & 6 & 0.5 & 54.19 & 3.40 & 5.29 \\
\hline 13 & \multirow{2}{*}{ Tamansari } & Barat & 4 & 3 & 49.63 & 3.32 & 4.60 \\
\hline 14 & & Timur & 4 & 3 & 55.55 & 3.33 & 4.70 \\
\hline 15 & \multirow{2}{*}{ Cikutra } & Barat & 4 & 0.5 & 17.95 & 3.30 & 4.19 \\
\hline 16 & & Timur & 4 & 0.5 & 25.04 & 3.30 & 4.28 \\
\hline 17 & \multirow{2}{*}{ Sulanjana } & Utara & 4 & 0.5 & 112.48 & 3.40 & 5.25 \\
\hline 18 & & \begin{tabular}{|l|} 
Selatan \\
\end{tabular} & 4 & 0.5 & 92.66 & 3.38 & 5.08 \\
\hline 19 & \multirow{2}{*}{ Cimuncang } & Barat & 4 & 0.5 & 24.91 & 3.30 & 4.29 \\
\hline 20 & & Timur & 4 & 0.5 & 23.43 & 3.30 & 4.20 \\
\hline 21 & \multirow{2}{*}{ Astana Anyar } & Utara & 4 & 0 & 36.82 & 3.32 & 4.42 \\
\hline 22 & & Selatan & 4 & 0 & 38.14 & 3.32 & 4.41 \\
\hline 23 & \multirow{2}{*}{ Lombok-Citarum } & Barat & 4 & 0 & 57.02 & 3.34 & 4.67 \\
\hline 24 & & Timur & 4 & 0 & 54.1 & 3.34 & 4.65 \\
\hline 25 & \multirow{2}{*}{ Cihapit } & Barat & 4 & 0 & 22.87 & 3.31 & 4.25 \\
\hline 26 & & Timur & 4 & 0 & 24.44 & 3.31 & 4.27 \\
\hline 27 & \multirow{2}{*}{ Trunojoyo } & Barat & 4 & 0 & 62.08 & 3.35 & 4.78 \\
\hline 28 & & Timur & 4 & 0 & 64.17 & 3.35 & 4.83 \\
\hline 29 & \multirow{2}{*}{ Banda-Aceh } & Barat & 2 & 0 & 19.9 & 3.24 & 3.56 \\
\hline 30 & & Timur & 2 & 0 & 19.08 & 3.24 & 3.54 \\
\hline 31 & \multirow{2}{*}{ Lombok-Aceh } & Utara & 2 & 0 & 20.12 & 3.24 & 3.56 \\
\hline 32 & & \begin{tabular}{|l|} 
Selatan \\
\end{tabular} & 2 & 0 & 20.47 & 3.24 & 3.57 \\
\hline
\end{tabular}

Berdasarkan hasil perhitungan nilai PedISI menggunakan model PedISI untuk simpang bersinyal Kota Bandung dalam Tabel 16, simpang yang memiliki nilai PedISI tertinggi adalah Simpang Gedebage dan Kiaracondong sedangkan simpang yang memiliki nilai PedISI terendah adalah Simpang Banda-Aceh dan Lombok-Aceh. Rata-rata nilai PedISI untuk Simpang Bersinyal Kota Bandung adalah 3,35 dengan standar deviasi sebesar 0,06.

\section{IV.8 Aplikasi Model PedISI Simpang Bersinyal Kota Bandung}

Selain melakukan perhitungan nilai PedISI pada setiap simpang, dilakukan pula perhitungan nilai PedISI berdasarkan tipe simpang dengan model PedISI yang terbentuk dan model PedISI yang dikembangkan oleh FHWA. Berikut ini adalah hasil perhitungan nilai PedISI berdasarkan tipe simpang untuk masing-masing model yang tersaji dalam Gambar 3, 4 dan 5.

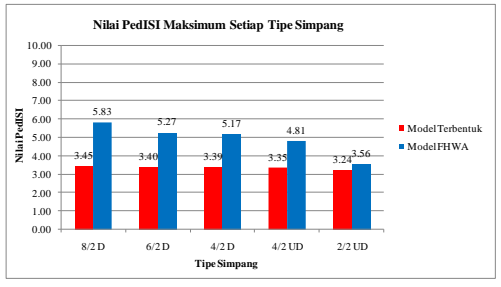

Gambar 3 Nilai PedISI Maksimum

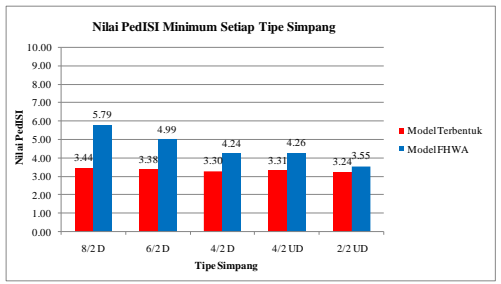

Gambar 4 Nilai PedISI Minimum

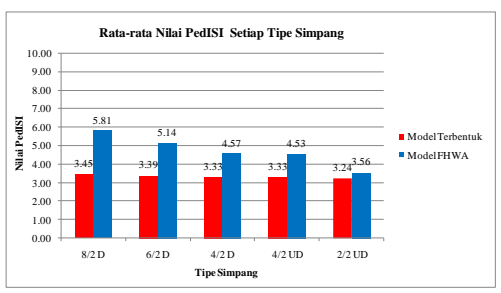

Gambar 5 Rata-rata Nilai PedISI

Nilai PedISI simpang dengan model PedISI yang dikembangkan dalam penelitian ini memiliki rata-rata nilai sebesar 3,35 dengan standar deviasi sebesar 0,06 sedangkan nilai PedISI simpang dengan model PedISI oleh FHWA memiliki rata-rata nilai sebesar 4,73 dengan standar deviasi 0,67. Standar deviasi yang kecil pada model PedISI untuk simpang bersinyal Kota Bandung menunjukkan bahwa varisi nilai PedISI kecil (data seragam). Hal ini dikarenakan pengaruh dari metode pengumpulan data. Pada saat pengumpulan data seharusnya setiap responden menilai keseluruhan tipe simpang sehingga dapat membedakan antara tipe simpang yang satu dan yang lainnya sedangkan dalam penelitian ini, pada saat pengumpulan data responden menilai 5 simpang secara acak. Selain itu, hasil data ini juga dipengaruhi oleh kuisoner yang kurang spesifik dalam menanyakan tentang tingkat keselamatan bagi pejalan kaki di simpang. Dalam kuisoner, lebih ditekankan terhadap keberadaan fasilitas penyeberangan jalan dan kondisi lalu lintas tanpa memberikan pertimbangan yang berkaitan dengan faktor dari pejalan kaki atau penyeberang jalan. 
Besarnya nilai PedISI pada kedua model sangat dipengaruhi oleh total jumlah lajur hal ini ditunjukkan dengan nilai PedISI yang semakin tinggi pada simpang yang memiliki banyak jumlah lajur karena banyaknya jumlah lajur mempengaruhi kesempatan interaksi antara pejalan kaki dengan kendaraan bermotor. Jumlah lajur yang semakin banyak membuat jarak dan waktu yang ditempuh untuk menyeberang semakin jauh dan lama sehingga kesempatan interaksi antara pejalan kaki dan kendaraan bermotor semakin besar yang dapat meningkatkan potensi terjadinya kecelakaan.

Selain dipengaruhi oleh total jumlah lajur, keberadaan median juga mempengaruhi besarnya nilai PedISI. Keberadaan median yang membuat nilai PedISI yang dihasilkan kedua model cukup jauh berbeda pada tipe simpang tanpa median yaitu simpang 4/2 UD dan simpang 2/2 UD. Nilai PedISI dari model yang terbentuk dalam penelitian untuk kedua tipe simpang jauh lebih tinggi dibandingkan dengan nilai PedISI dari model yang dikembangkan oleh FHWA.

Hal ini dikarenakan pada model yang dikembangkan oleh FHWA tidak dipengaruhi oleh keberadaan median sehingga nilai PedISInya jauh lebih kecil sedangkan pada model yang terbentuk dalam penelitian ini, keberadaan median sangat mempengaruhi nilai PedISI. Adanya median pada jalan yang dilintasi oleh pejalan kaki pada simpang dapat mengurangi besar nilai PedISI karena median mampu meningkatkan tingkat keselamatan bagi pejalan kaki karena dapat mengurangi konflik dan melindungi pejalan kaki sebagai tempat berhenti sementara ketika pejalan kaki tidak dapat melanjutkan proses menyeberang.

\section{KESIMPULAN DAN SARAN}

Kesimpulan yang dapat diambil dari hasil pengolahan dan analisis data dalam penelitian ini adalah sebagai berikut:

1. Variabel yang berpengaruh dalam membangun model keselamatan untuk penyeberangan jalan Kota Bandung adalah Total Jumlah Lajur (X3), Lebar Median (X7) dan Kecepatan 85 Persentil (X10).

2. Model PedISI yang terbentuk adalah PedISI $=$ $3,184+0,032$ THRULNS - 0,005MEDIAN + 0,001 SPEED85 $^{\text {th }}$ dengan $\mathrm{R}^{2}=0,525$. Nilai PedISI berdasarkan model yang terbentuk adalah 3,24 -
3,45. Besar rata-rata nilai PedISi sebesar 3,35 dengan standar deviasi 0,06 sedangkan nilai PedISI dari model PedISI yang dikembangkan FHWA sebesar $3,56-5,88$. Besar rata-rata nilai PedISi sebesar 4,73 dengan standar deviasi sebesar 0,67.

3. Nilai PedISI untuk simpang bersinyal Kota Bandung dipengaruhi oleh banyaknya total jumlah lajur, keberadaan median dan kecepatan 85 persentil. Semakin banyak total jumlah lajur maka semakin tinggi nilai PedISI karena jumlah lajur sangat mempengaruhi lamanya interaksi yang dapat terjadi antara pejalan kaki dan kendaraan bermotor. Seiring dengan semakin tinggi kecepatan kendaraan di jalan yang dilintasi maka nilai PedISI juga semakin tinggi karena potensi kecelakaan semakin besar. Berbeda dengan total jumlah lajur dan kecepatan, keberadaan median dapat mengurangi keselamatan bagi pejalan kaki karena mengurangi konflik dan sebagai tempat berhenti sementara bagi pejalan kaki.

\section{Saran}

Guna mendapatkan model yang lebih baik untuk menilai tingkat keselamatan bagi pejalan kaki di Simpang Bersinyal Kota Bandung, dalam pengembang model ini ada beberapa saran sebagai berikut:

1. Dalam mengidentifikasi variabel-variabel bebas yang berpotensi mempengaaruhi tingkat keselamatan bagi pejalan kaki di simpang bersinyal, perlu dipertimbangkan karakteristik pejalan kaki seperti kecepatan berjalan dan menyeberang dan volume pejalan kaki pada simpang yang ditinjau.

2. Mempertimbangkan pengaruh dari lebar area penyeberangan jalan dibanding dengan total jumlah lajur.

3. Memperbaiki metode pengumpulan data pada saat survei mengenai persepsi pejalan kaki terhadap tingkat keselamatan di simpang sehingga model yang dihasilkan akan memiliki variasi nilai PedISI yang lebih baik.

4. Pengembangan model tidak hanya meninjau simpang bersinyal 4 lengan saja tetapi juga meninjau simpang bersinyal 3 lengan serta simpang tak bersinyal sehingga model dapat lebih baik menggambarkan nilai tingkat keselamatan 


\section{REFERENSI}

Abraham, J., (2001): Analysis of Highway Speed Limits, Bachelor Degree Thesis, Faculty of Applied Science and Engineering, University Toronto, Canada.

Carter, et al., (2007): Pedestrian and bicyclist interection safety indices: user guide. University of North Carolina, Highway Safety Research Center. McLean: Federal Highway Administration.

Listiyani, Y dan Purhadi, (2010): Pemodelan Generalized Regresi Poisson pada Faktor Faktor yang Mempengaruhi Angka Kematian Bayi di Provinsi Jawa Timur Tahun 2007. Jurnal Statistika ITS, 2(2007): 1-7.

Zegeer, C., Seiderman, C., Lagerway, P., Cynecki, M., Ronkin, M., \& Schneider, R., (2002): Pedestrian facilities users guide - providing safety and mobility. University of North Carolina, Highway Safety Research Center. McLean: Federal Highway Administration. 